\title{
IDENTIFIKASI KOMPETENSI GURU SEBAGAI CERMINAN PROFESIONALISME TENAGA PENDIDIK DI KABUPATEN SUMEDANG (KAJIAN PADA KOMPETENSI PEDAGOGIK)
}

\author{
1) Deni Suhandani' ${ }^{12}$ Julia
}

${ }^{1}$ Litbang Bappeda Kabupaten Sumedang

J1. Prabu Geusan Ulun No. 36 Sumedang

Email: mz_den@yahoo.com

\begin{abstract}
This paper examines one of the main teachers' competence, ie pedagogical competence of teachers who have been certified educators in Sumedang district. This type of research is a survey research with descriptive-quantitative method. The population was 592 certified teachers in the district of North and South Sumedang, with a sample of 60 teachers. Data collected through questionnaire (Likert scale) on the respondent one (R1) is a certified teacher of 60 people, two respondents (R2) are colleagues who have not been certified 60 people, and three respondents (R3) is the principal of 60 people, so total respondents amounted to 180 people. Processing and data analysis was performed using SPSS 16 through frequency analysis and correlation. The results stated that the average pedagogical competence of teachers at the GOOD category, with the acquisition value of 3.02 (75.48\%). However, when seen by the results of the correlation answer, where answer between $R 1$ and $R 2$ are many significant / agree, but the answers are not many significant R3 / contrary, it can be concluded that the average pedagogical abilities certified teacher educators in Sumedang district, is in the category ENOUGH based on answers from 150 respondents (84.3\%), and is in the category GOOD based on answers from 28 respondents $(15.7 \%)$.
\end{abstract} Keywords: pedagogical competence, professionalism, teacher, sumedang. Tulisan ini mengkaji tentang salahsatu kompetensi guru, yaitu kompetensi pedagogik pada guru yang telah bersertifikat pendidik di kabupaten Sumedang. Jenis penelitian adalah penelitian survei dengan metode deskriptif-kuantitatif. Populasinya adalah 592 guru tersertifikasi di kabupaten Sumedang Utara dan Sumedang Selatan, dengan sampel 60 guru. Pengumpulan data dilakukan melalui kuisioner (skala Likert) pada responden satu (R1) yaitu guru tersertifikasi sebanyak 60 orang, responden dua (R2) yaitu teman sejawat yang belum tersertifikasi 60 orang, dan responden tiga (R3) yaitu kepala sekolah sebanyak 60 orang, sehingga total responden berjumlah 180 orang. Pengolahan dan analisis data dilakukan dengan menggunakan program SPSS 16 melalui analisis frekuensi dan korelasi. Hasil yang diperoleh menyatakan bahwa rata-rata kompetensi pedagogik guru berada pada kategori BAIK, dengan perolehan nilai 3,02 (75,48\%). Namun apabila dilihat berdasarkan hasil korelasi jawaban, dimana jawaban antara R1 dan R2 banyak yang signifikan/sependapat, namun jawaban $R 3$ banyak yang tidak signifikan/bertentangan, maka dapat diperoleh kesimpulan bahwa rata-rata kemampuan pedagogis guru bersertifikat pendidik di kabupaten Sumedang, berada pada kategori CUKUP berdasarkan jawaban dari 150 responden (84,3\%), dan berada pada kategori BAIK berdasarkan jawaban dari 28 responden $(15,7 \%)$.

Kata Kunci: kompetensi pedagogik, profesionalisme, guru, sumedang.

PENDAHULUAN Seperti yang dipaparkan pada hasil penelitian Fahdini, dkk (2013), bahwa wacana yang beredar di kabupaten Sumedang mengenai guru tersertifikasi yang dianggap guru profesional namun belum mampu berbuat secara profesional, mengimplementasikan khususnya profesionalnya, ternyata terbukti benar. Sebagaimana dilaporkan bahwa, jika dilihat dari lima aspek yang dinilai dari kompetensi guru 
berdasarkan rating scale, diperoleh gambaran bahwa kompetensi profesional guru tersertifikasi di kabupaten Sumedang, empat aspek berada pada kategori 'CUKUP' dan satu aspek berada pada kategori 'KURANG'. Kondisi ini masih jauh dari kategori 'PROFESIONAL'. Sementara ditinjau dari skala sikap terhadap kompetensi profesional guru secara keseluruhan, maka dapat disimpulkan bahwa pada umumnya guru tersertifikasi di kabupaten Sumedang tergolong pada kategori 'BAIK'. Namun kondisi ini pun masih jauh dari kategori 'PROFESIONAL' (Reni Fahdini, dkk, 2013:47).

Kenyataan ini tentu saja mengundang tanda tanya dan kepenasaran pada kemampuan tiga kompetensi lainnya. Maka dari itu, diperlukan penelitian secara mendetail pada tiga kompetensi lainnya, supaya benar-benar didapatkan gambaran yang sebenarnya dan terkini dari kondisi profesionalisme guru, terutama para guru yang telah dinyatakan sebagai guru profesional melalui pemerolehan sertifikasi guru. Sehingga apa yang dicita-citakan oleh pemerintah kabupaten Sumedang terutama yang berkaitan dengan peningkatan kualitas pendidikan di kabupaten Sumedang dapat terlaksana dengan baik.

Melalui penelitian ini, akan dilanjutkan untuk mengkaji kompetensi guru di kabupaten Sumedang, yang dikhususkan pada kompetensi pedagogik. Satu kompetensi ini layak untuk dikaji secara mandiri mengingat aspek-aspek beserta indikator yang terdapat di dalamnya cukup banyak sehingga sangat memungkinkan untuk diteliti atau dikaji secara terpisah, sebagaimana layaknya kompetensi profesional yang telah dikaji lebih dulu.

Kompetensi pedagogik sebagaimana diungkapkan oleh Mulyasa (Yulianti, 2012:112), yaitu kemampuan mengelola pembelajaran peserta didik yang meliputi pemahaman peserta didik, perancangan dan pelaksanaan pembelajaran, evaluasi hasil belajar, dan pengembangan peserta didik untuk mengaktualisasikan berbagai potensi yang dimilikinya. Dengan demikian, penelitian ini akan secara spesifik mengkaji persoalan kemampuan guru yang terkait dengan ilmu-ilmu tentang pendidikan, lebih khusus tentang bagaimana mengelola pembelajaran.
Topik ini pun selaras dengan berbagai persoalan yang mencuat di kalangan guru-guru di kabupaten Sumedang, seperti yang teridentifikasi melalui perkuliahan dual modes dan PLPG, bahwa pada umumnya guru-guru sekolah dasar kurang memahami berbagai teori belajar dan prinsip-prinsip pembelajaran yang mendidik, jarang menerapkan berbagai pendekatan, strategi, metode, dan teknik pembelajaran yang mendidik secara kreatif, kurang memahami prinsip-prinsip penilaian dan evaluasi proses dan hasil belajar sesuai dengan karakteristik bidang studi, jarang melakukan refleksi terhadap pembelajaran yang telah dilaksanakan, dan lain-lain. Yang mana semua permasalahan tersebut berada pada koridor kemampuan pedagogik.

Oleh sebab itu, penelitian ini dipandang penting untuk dilakukan mengingat kabupaten Sumedang memiliki visi dan misi yang antara lain ingin membangun kualitas pendidikan yang lebih baik, dan rencana tersebut tentu saja mesti berdasarkan pada kajian di lapangan, sehingga apa yang dilakukan sesuai dengan kebutuhan yang sebenarnya dan terjadi di lapangan. Dengan mengetahui kondisi yang sebenarnya, pemerintah daerah setempat pun tentu saja akan lebih bertindak solutif dan konstruktif.

Untuk memberikan batasan dan memfokuskan kajian, maka penelitian ini hanya mengidentifikasi kompetensi pedagogik guruguru SD yang tersertifikasi di kabupaten Sumedang? Yang terdiri atas 10 aspek sebagai berikut:

1. Bagaimana kemampuan guru dalam menguasai karakteristik peserta didik dari aspek fisik, moral, sosial, kultural, emosional, dan intelektual?

2. Bagaimana kemampuan guru dalam menguasai teori belajar dan prinsip-prinsip pembelajaran yang mendidik?

3. Bagaimana kemampuan guru dalam mengembangkan kurikulum yang terkait dengan mata pelajaran/bidang pengembangan yang diampu?

4. Bagaimana kemampuan guru dalam menyelenggarakan pembelajaran yang mendidik?

5. Bagaimana kemampuan guru dalam memanfaatkan teknologi informasi dan 
komunikasi untuk kepentingan pembelajaran?

6. Bagaimana kemampuan guru dalam memfasilitasi pengembangan potensi peserta didik untuk mengaktualisasikan berbagai potensi yang dimiliki?

7. Bagaimana kemampuan guru dalam berkomunikasi secara efektif, empatik, dan santun dengan peserta didik?

8. Bagaimana kemampuan guru dalam menyelenggarakan penilaian dan evaluasi proses dan hasil belajar?

9. Bagaimana kemampuan guru dalam memanfaatkan hasil penilaian dan evaluasi untuk kepentingan pembelajaran?

10. Bagaimana kemampuan guru dalam melakukan tindakan reflektif untuk peningkatan kualitas pembelajaran?

\section{Kompetensi Guru}

Dalam undang-undang No.14 tahun 2005 pada pasal 10 ayat 1 dijelaskan bahwa guru harus memiliki empat kompetensi dalam mengajar untuk menunjang pribadi guru agar menjadi guru yang profesional. Adapun kompetensi yang harus dimiliki oleh guru adalah:

a. Kompetensi pedagogik

Adalah kemampuan mengelola pembelajaran peserta didik yang meliputi pemahaman terhadap peserta didik, perancangan dan pelaksanaan pembelajaran, evaluasi hasil belajar, dan pengembangan peserta didik untuk mengaktualisasikan berbagai potensi yang dimilikinya.

b. Kompetensi kepribadian

Adalah kepribadian pendidik yang mantap, stabil, dewasa, arif, dan berwibawa, menjadi teladan bagi peserta didik, dan berakhlak mulia.

c. Kompetensi sosial

Adalah kemampuan pendidik berkomunikasi dan berinteraksi secara efektif dengan peserta didik, sesama pendidik, tenaga kependidikan, orang tua/wali peserta didik, dan masyarakat.

d. Kompetensi profesional

Adalah kemampuan pendidik dalam penguasaan materi pembelajaran secara luas dan mendalam yang memungkinkannya membimbing peserta didik memperoleh kompetensi yang ditetapkan.

\section{Kompetensi Pedagogik}

Yasin (2011:164-165) memaparkan bahwa kompetensi pedagogik adalah kemampuan seorang pendidik dalam mengelola pembelajaran peserta didik yang meliputi;

a. Kemampuan dalam memahami peserta didik, dengan indikator antara lain; (a). Memahami karakteristik perkembangan peserta didik, seperti memahamai tingkat kognisi peserta didik sesuai dengan usianya. (b). Memahami prinsip-prinsip perkembangan kepribadian peserta didik, seperti mengenali tipe-tipe kepribadian peserta didik, mengenali tahapan tahapan perkembangan kepribadian peserta didik, dan lainnya. (c). Mampu mengidentifikasi bekal ajar awal peserta didik, seperti mengukur potensi awal peserta didik, mengenali perbedaan potensi yang dimiliki peserta didik, dan lain sebagainya.

b. Kemampuan dalam membuat perancangan pembelajaran, dengan indikator antara lain; (a). Mampu Merencanakan pengorganisasian bahan pembelajaran, seperti mampu menelaah dan menjabarkan materi yang tercantum dalam kurikulum, mampu memilih bahan ajar yang sesuai dengan materi, mampu mengunakan sumber belajar yang memadai, dan lainnya. (b). Mampu merencanakan pengelolaan pembelajaran, seperti merumuskan tujuan pembelajaran yang ingin dicapai sesuai dengan kompetensi yang ingin dicapai, memilih jenis strategi/metode pembelajaran yang cocok, menentukan langkah-langkah pembelajaran, menentukan cara yang dapat digunakan untuk memotivasi peeserta didik, menentukan bentuk-bentuk pertanyaan yang akan diajukan kepada peeserta didik, dan lainnya. (c). Mampu merencanakan pengelolaan kelas, seperti penataan ruang tempat duduk peeserta didik, mengalokasikan waktu, dan lainnya. (d). Mampu merencanakan penggunaan media dan sarana yang bisa digunakan untuk mempermudah pencapaian kompetensi, dan lainnya, (e). Mampu merencanakan model penilaian proses pembelajaran, seperti menentukan bentuk, prosedur, dan alat penilaian. 
c. Kemampuan melaksanakan pembelajaran, dengan indikator antara laian; (a). Mampu menerapkan ketrampilan dasar mengajar, seperti membuka pelajaran, menjelaskan, pola variasi, bertanya, memberi penguatan, dan menutup pelajaran. (b). Mampu menerapkan berbagai jenis pendekatan, strategi.metode pembelajaran, seperti aktif learning, CTL, pembelajaran portofolio, pembelajaran kontekstual dan lainnya. (c) Mampu menguasai kelas, seperti mengaktifkan peeserta didik dalam bertanya, mampu menjawab dan mengarahkan pertanyaan siswa, kerja kelompok, kerja mandiri, dan lainnya. (d). Mampu mengukur tingkat ketercapaian kompetensi peeserta didik selama proses pembelajaran berlangsung.

d. Kemampuan dalam mengevaluasi hasil belajar, dengan indikator antara lain; (a). Mampu merancang dan melaksanakan asesmen, seperti memahami prinsip-prinsif assesment, mampu menyususn macammacam instrumen evaluasi pembelajaran, mampu melaksanakan evaluasi, dan lainnya. (b). Mampu menganalisis hasil assessment, seperti mampu mengolah hasil evaluasi pembelajaran, mampu mengenali karakteristik instrumen evaluasi. (c). Mampu memanfaatkan hasil asesment untuk perbaikan kualitas pembelajaran selanjutnya, seperti memanfaatkan hasil analisis instrumen evaluasi dalam proses perbaikan instrumen evaluasi, dan mampu memberikan umpan balik terhadap perbaikan perencanaan, pelaksanaan dan evaluasi pembelajaran. 5. Kemampuan dalam megembangkan peserta didik untuk mengaktualisasikan berbagai potensi yang dimilikinya, dengan indikator antara lain; (a). Memfasilitasi peserta didik untuk mengembangkan potensi akademik, seperti menyalurkan potensi akademik peserta didik sesuai dengan kemampuannya, mampu mengarahkan dan mengembangkan potensi akademik peserta didik. (b). Mampu memfasilitasi peserta didik untuk mengembangkan potensi nonakademik, seperti menyalurkan potensi non-akademik peserta didik sesuai dengan kemampuannya, mampu mengarahkan dan mengembangkan potensi non-akademik peserta didik.

\section{Profesionalisme Guru}

Dalam UUGD Pasal 1 ayat 5, disebutkan bahwa profesional adalah pekerjaan atau kegiatan yang dilakukan oleh seseorang dan menjadi sumber penghasilan kehidupan yang memerlukan keahlian, kemahiran, atau kecakapan yang memenuhi standar mutu atau norma tertentu serta memerlukan pendidikan profesi. Dengan demikian, guru yang profesional adalah guru yang memiliki keahlian sesuai dengan standar mutu pendidikan yang ditetapkan oleh pemerintah.

Namun demikian, seseorang yang berprofesi sebagai guru belum tentu bersikap profesional, karena seperti dikatakan oleh Danim (2002:23), bahwa orang yang profesional memiliki sikapsikap yang berbeda dengan orang yang tidak profesional meskipun dalam pekerjaan yang sama atau katakanlah berada pada satu ruang kerja. Maka dari itu, guru profesional senantiasa memiliki ciri tersendiri dalam kesehariannya untuk selalu menunjukan kemahirannya sebagai guru.

Lebih lanjut Danim (2002:23) mengatakan bahwa profesionalisme dapat diartikan sebagai komitmen para anggota suatu profesi untuk meningkatkan kemampuan profesionalnya dan terus-menerus mengembangkan strategi-strategi yang digunakannya dalam melakukan pekerjaan sesuai dengan profesinya itu. Oleh karenanya, guru yang profesional senantiasa berupaya untuk meningkatkan kualitas diri dan senantiasa untuk mengupdate pengetahuannya secara kontinyu.

Beberapa aspek yang dapat mencerminkan guru profesional antara lain berhubungan dengan penyelesaian tugas-tugas keguruan sebagai berikut.

1. Menguasai landasan kependidikan.

2. Memahami bidang psikologi pendidikan.

3. Menguasai materi pelajaran.

4. Mampu mengaplikasikan berbagai metodologi dan strategi pembelajaran.

5. Mampu dalam merancang dan memanfaatkan berbagai media dan sumber belajar.

6. Mampu dalam melaksanakan evaluasi pembelajaran. 
7. Mampu dalam menyusun program pembelajaran.

8. Mampu dalam melaksanakan unsur-unsur penunjang.

9. Mampu dalam melaksanakan penelitian dan berpikir ilmiah untuk meningkatkan kinerja.

Untuk memprofesionalkan suatu pekerjaan, termasuk profesi sebagai guru, Wilensky (1976) merumuskan ada lima langkah, yakni:

1. Memunculkan suatu pekerjaan yang penuh waktu atau full-time, bukan pekerjaan sambilan.

2. Menetapkan sekolah sebagai tempat menjalani proses pendidikan atau pelatihan.

3. Mendirikan asosiasi profesi.

4. Melakukan agitasi secara politis untuk memperjuangkan adanya perlindungan hukum terhadap asosiasi atau perhimpunan tersebut.

5. Mengadopsi secara formal kode etik yang ditetapkan (Danim, 2002:29).

\section{Sertifikasi Guru}

Widoyoko (2008:4) memaparkan bahwa sertifikasi guru adalah proses pemberian sertifikat pendidik kepada guru. Sertifikasi guru tersebut bertujuan untuk:

1. Menentukan kelayakan guru dalam melaksanakan tugas sebagai agen pembelajaran dan mewujudkan tujuan pendidikan nasional.

2. Meningkatkan proses dan mutu hasil pendidikan.

3. Meningkatkan martabat guru.

4. Meningkatkan profesionalitas guru.

Adapun manfaat sertifikasi guru dapat dirinci sebagai berikut.

1. Melindungi profesi guru dari praktikpraktik yang tidak kompeten, yang dapat merusak citra profesi guru.

2. Melindungi masyarakat dari praktik-praktik pendidikan yang tidak bermutu dan tidak profesional.

3. Meningkatkan kesejahteraan guru.

Sertifikasi guru merupakan upaya peningkatan mutu guru yang diikuti dengan peningkatan kesejahteraan guru, sehingga diharapkan dapat meningkatkan mutu pembelajaran dan mutu pendidikan di Indonesia secara berkelanjutan (Depdiknas, 2008:1; Widoyoko, 2008:4).

\section{METODE}

Metode Penelitian

Penelitian ini merupakan penelitian survei dengan metode penelitian berbentuk kuantitatifdeskriptif. Metode kuantitatif digunakan untuk melakukan pengukuran-pengukuran, sedangkan metode deskriptif bertujuan untuk membuat deskripsi, gambaran atau lukisan secara sistematis, faktual dan akurat mengenai faktafakta, sifat-sifat serta hubungan antarfenomena yang diselidiki (Nazir, 2005:54). Dengan demikian, metode kuantitatif-deskriptif ini digunakan untuk mengukur dan mendeskripsikan dengan jelas dan rinci mengenai kompetensi pedagogik guru-guru di kabupaten Sumedang.

\section{Setting Penelitian}

\section{Waktu dan Tempat Penelitian}

Penelitian dilakukan selama tiga bulan, mulai dari bulan Juni sampai dengan bulan Agustus 2014 pada kategori kawasan perkotaan di kabupaten Sumedang, yaitu kecamatan Sumedang Utara dan Sumedang Selatan. Melalui kategori kawasan tersebut, diharapkan kompetensi pedagogik guru-guru tersertifikasi di kabupaten Sumedang dapat tergambar dengan jelas.

\section{Subjek Penelitian}

Subjek dalam penelitian ini adalah para guru tersertifikasi dari tingkat sekolah dasar, dengan objek penelitiannya adalah kompetensi pedagogik. Populasi yang digunakan berjumlah 592 guru dengan jumlah sampel sebesar 10\% yakni sekitar 60 guru tersertifikasi.

\section{Teknik Pengumpulan Data}

Pengumpulan data dilakukan dengan menggunakan metode angket atau kuisioner dengan jenis instrumen daftar cek (checklist). Menurut Bungin (2006:123), metode angket merupakan serangkaian atau daftar pertanyaan yang disusun secara sistematis, kemudian dikirim untuk diisi oleh responden. Setelah diisi, angket dikirim kembali atau dikembalikan ke petugas atau peneliti. Seperti dalam penelitian ini, peneliti menyebarkan angket untuk diisi oleh responden yakni para 60 guru yang sudah disertifikasi, 60 guru teman sejawat yang belum disertifikasi, dan 60 kepala sekolah, kemudian 
diambil kembali untuk dilakukan pengolahan data. Dengan demikian, data yang diolah berasal dari 180 responden.

Namun karena setelah dilakukan pengumpulan data, dua responden (R1 dan R2) tidak mengembalikan/tidak mengisi angket, maka total responden berjumlah 178 orang, dan kekurangan dua responden ini tidak berpengaruh secara signifikan terhadap hasil penelitian.

\section{Teknik Analisis Data}

Pengukuran dalam penelitian ini terdiri atas sepuluh aspek yang kesepuluh aspek tersebut kemudian dijabarkan kembali menjadi 38 indikator. Kesepuluh aspek yang dijabarkan melalui 38 indikator tersebut kemudian dituangkan ke dalam sebuah angket dengan bentuk skala Likert. Pada skala ini, disajikan pilihan Kurang (K), Cukup (C), Baik (B), dan Sangat Baik (SB). Masing-masing butir pilihan tersebut kemudian diberi bobot yang berbeda, yakni:

$\begin{array}{ll}\text { Kurang (K) } & =1 \\ \text { Cukup (C) } & =2 \\ \text { Baik (B) } & =3 \\ \text { Sangat Baik (SB) } & =4\end{array}$

Untuk mengolah semua data yang terkumpul lewat angket skala likert di atas, dilakukan analisis dengan menggunakan program SPSS 16. Yang kemudian ditafsirkan ke dalam empat skala interpretasi, yakni sebagai berikut:

Tabel 1. Rentang Skala Interpretasi (Skala Empat) SPSS 16

\begin{tabular}{|c|c|c|}
\hline Skor & Rentang Nilai & Interpretasi \\
\hline 4 & $3,5-4$ & Sangat Baik \\
\hline 3 & $2,5-3,4$ & Baik \\
\hline 2 & $1,5-2,4$ & Cukup \\
\hline 1 & $1-1,4$ & Kurang \\
\hline
\end{tabular}

Jenis analisis data yang digunakan meliputi analisis frekuensi dan analisis korelasi Pearson. Menurut Priyatno (2012), analisis frekuensi digunakan untuk menghitung frekuensi data pada variabel, analisis statistik, serta menampilkan grafik. Sementara analisis Pearson (Product Moment Pearson) digunakan untuk mengukur keeratan hubungan antara dua variabel yang mempunyai distribusi data normal. Maka dari itu, dalam penelitian ini analisis frekuensi digunakan untuk mengetahui jumlah pemberi jawaban dari setiap pertanyaan dalam kuisioner, dan analisis korelasi digunakan untuk melihat sejauh mana objektivitas atau kebenaran data yang dipersepsi oleh responden satu, responden dua, dan responden tiga.

\section{HASIL DAN PEMBAHASAN}

\section{Hasil Analisis Frekuensi}

Berdasarkan analisis program SPSS 16 pada aspek analisis frekuensi, didapatkan hasil sebagai berikut:

a. Pengukuran kompetensi pedagogik terhadap kemampuan guru dalam menguasai karakteristik peserta didik dari aspek fisik, moral, sosial, kultural, emosional, dan intelektual.

\begin{tabular}{|l|l|r|r|r|r|}
\hline & & Frequency & Percent & Valid Percent & $\begin{array}{c}\text { Cumulative } \\
\text { Percent }\end{array}$ \\
\hline Valid & Cukup & 1 & .6 & .6 & .6 \\
\cline { 2 - 6 } & Baik & 157 & 88.2 & 88.2 & 88.8 \\
\cline { 2 - 6 } & Sangat Baik & 20 & 11.2 & 11.2 & 100.0 \\
\cline { 2 - 6 } & Total & 178 & 100.0 & 100.0 & \\
\hline
\end{tabular}

b. Pengukuran kompetensi pedagogik terhadap kemampuan guru dalam menguasai teori belajar dan prinsip-prinsip pembelajaran yang mendidik. 


\begin{tabular}{|l|l|r|r|r|r|}
\hline & & Frequency & Percent & Valid Percent & $\begin{array}{l}\text { Cumulative } \\
\text { Percent }\end{array}$ \\
\hline \multirow{3}{*}{ Valid } & Cukup & 15 & 8.4 & 8.4 & 8.4 \\
\cline { 2 - 6 } & Baik & 150 & 84.3 & 84.3 & 92.7 \\
\cline { 2 - 6 } & Sangat Baik & 13 & 7.3 & 7.3 & 100.0 \\
\cline { 2 - 6 } & Total & 178 & 100.0 & 100.0 & \\
\hline
\end{tabular}

c. Pengukuran kompetensi pedagogik terhadap kemampuan guru dalam mengembangkan kurikulum yang terkait dengan mata pelajaran/bidang pengembangan yang diampu.

\begin{tabular}{|l|l|r|r|r|r|}
\hline & & Frequency & Percent & Valid Percent & $\begin{array}{c}\text { Cumulative } \\
\text { Percent }\end{array}$ \\
\hline \multirow{3}{*}{ Valid } & Cukup & 1 & .6 & .6 & .6 \\
\cline { 2 - 6 } & Baik & 161 & 90.4 & 90.4 & 91.0 \\
\cline { 2 - 6 } & Sangat Baik & 16 & 9.0 & 9.0 & 100.0 \\
\cline { 2 - 6 } & Total & 178 & 100.0 & 100.0 & \\
\hline
\end{tabular}

d. Pengukuran kompetensi pedagogik terhadap kemampuan guru dalam menyelenggarakan pembelajaran yang mendidik.

\begin{tabular}{|l|l|r|r|r|r|}
\hline & & Frequency & Percent & Valid Percent & $\begin{array}{c}\text { Cumulative } \\
\text { Percent }\end{array}$ \\
\hline Valid & Cukup & 7 & 3.9 & 3.9 & 3.9 \\
\cline { 2 - 6 } & Baik & 163 & 91.6 & 91.6 & 95.5 \\
\cline { 2 - 6 } & Sangat Baik & 8 & 4.5 & 4.5 & 100.0 \\
\cline { 2 - 6 } & Total & 178 & 100.0 & 100.0 & \\
\hline
\end{tabular}

e. Pengukuran kompetensi pedagogik terhadap kemampuan guru dalam memanfaatkan teknologi informasi dan komunikasi untuk kepentingan pembelajaran.

\begin{tabular}{|l|l|r|r|r|r|}
\hline & & Frequency & Percent & Valid Percent & $\begin{array}{l}\text { Cumulative } \\
\text { Percent }\end{array}$ \\
\hline \multirow{3}{*}{ Valid } & Kurang & 3 & 1.7 & 1.7 & 1.7 \\
\cline { 2 - 6 } & Cukup & 39 & 21.9 & 21.9 & 23.6 \\
\cline { 2 - 6 } & Baik & 122 & 68.5 & 68.5 & 92.1 \\
\cline { 2 - 6 } & Sangat Baik & 14 & 7.9 & 7.9 & 100.0 \\
\cline { 2 - 6 } & Total & 178 & 100.0 & 100.0 & \\
\hline
\end{tabular}

f. Pengukuran kompetensi pedagogik terhadap kemampuan guru dalam memfasilitasi pengembangan potensi peserta didik untuk mengaktualisasikan berbagai potensi yang dimiliki.

\begin{tabular}{|l|l|r|r|r|r|}
\hline & & Frequency & Percent & Valid Percent & \multicolumn{2}{c|}{$\begin{array}{c}\text { Cumulative } \\
\text { Percent }\end{array}$} \\
\hline Valid & Cukup & 14 & 7.9 & 7.9 & 7.9 \\
\hline
\end{tabular}


Mimbar Sekolah Dasar, Volume 1 Nomor 2 Oktober 2014, (hal. 128-141)

\begin{tabular}{|l|l|r|r|r|r|}
\hline Baik & 152 & 85.4 & 85.4 & 93.3 \\
\cline { 2 - 6 } & Sangat Baik & 12 & 6.7 & 6.7 & 100.0 \\
\cline { 2 - 6 } & Total & 178 & 100.0 & 100.0 & \\
\hline
\end{tabular}

g. Pengukuran kompetensi pedagogik terhadap kemampuan guru dalam berkomunikasi secara efektif, empatik, dan santun dengan peserta didik.

\begin{tabular}{|l|l|r|r|r|r|}
\hline & & & & \multicolumn{2}{c|}{$\begin{array}{c}\text { Cumulative } \\
\text { Percent }\end{array}$} \\
\hline \multirow{3}{*}{ Valid } & Cukup & 4 & 2.2 & 2.2 & 2.2 \\
\cline { 2 - 6 } & Baik & 148 & 83.1 & 83.1 & 85.4 \\
\cline { 2 - 6 } & Sangat Baik & 26 & 14.6 & 14.6 & 100.0 \\
\cline { 2 - 6 } & Total & 178 & 100.0 & 100.0 & \\
\hline
\end{tabular}

h. Pengukuran kompetensi pedagogik terhadap kemampuan guru dalam menyelenggarakan penilaian dan evaluasi proses dan hasil belajar.

\begin{tabular}{|l|l|r|r|r|r|}
\hline & Frequency & Percent & Valid Percent & $\begin{array}{c}\text { Cumulative } \\
\text { Percent }\end{array}$ \\
\hline \multirow{5}{*}{ Valid } & Cukup & 2 & 1.1 & 1.1 & 1.1 \\
\cline { 2 - 6 } & Baik & 164 & 92.1 & 92.1 & 93.3 \\
\cline { 2 - 6 } & Sangat Baik & 12 & 6.7 & 6.7 & 100.0 \\
\cline { 2 - 6 } & Total & 178 & 100.0 & 100.0 & \\
\hline
\end{tabular}

i. Pengukuran kompetensi pedagogik terhadap kemampuan guru dalam memanfaatkan hasil penilaian dan evaluasi untuk kepentingan pembelajaran.

\begin{tabular}{|l|l|r|r|r|r|}
\hline & & & & $\begin{array}{c}\text { Cumulative } \\
\text { Percent }\end{array}$ \\
\hline \multirow{3}{*}{ Valid } & Cukup & 1 & .6 & .6 & .6 \\
\cline { 2 - 6 } & Baik & 160 & 89.9 & 89.9 & 90.4 \\
\cline { 2 - 6 } & Sangat Baik & 17 & 9.6 & 9.6 & 100.0 \\
\cline { 2 - 6 } & Total & 178 & 100.0 & 100.0 & \\
\hline
\end{tabular}

j. Pengukuran kompetensi pedagogik terhadap kemampuan guru dalam melakukan tindakan reflektif untuk peningkatan kualitas pembelajaran.

\begin{tabular}{|l|l|r|r|r|r|}
\hline & & Frequency & Percent & Valid Percent & $\begin{array}{c}\text { Cumulative } \\
\text { Percent }\end{array}$ \\
\hline \multirow{3}{*}{ Valid } & Cukup & 6 & 3.4 & 3.4 & 3.4 \\
\cline { 2 - 6 } & Baik & 165 & 92.7 & 92.7 & 96.1 \\
\cline { 2 - 6 } & Sangat Baik & 7 & 3.9 & 3.9 & 100.0 \\
\cline { 2 - 6 } & Total & 178 & 100.0 & 100.0 & \\
\hline
\end{tabular}


Berdasarkan data frekuensi, maka dapat diidentifikasi bahwa rata-rata penilaian terhadap kemampuan pedagogis guru bersertifikat pendidik dari semua kelompok responden adalah sebagai berikut:

\begin{tabular}{|l|l|r|r|r|r|}
\hline \multicolumn{7}{|c|}{ Rata-rata } \\
\hline \multirow{3}{*}{} & & Frequency & Percent & Valid Percent & $\begin{array}{c}\text { Cumulative } \\
\text { Percent }\end{array}$ \\
\hline Valid & Baik & 171 & 96.1 & 96.1 & 96.1 \\
\cline { 2 - 6 } & Sangat Baik & 7 & 3.9 & 3.9 & 100.0 \\
\cline { 2 - 6 } & Total & 178 & 100.0 & 100.0 & \\
\hline
\end{tabular}

Melalui tabel di atas, dapat dijabarkan bahwa rata-rata kemampuan pedagogis guru bersertifikat pendidik di kabupaten Sumedang, berada pada kategori BAIK menurut 96,1\% responden, dan berada pada kategori SANGAT BAIK menurut 3,9\% responden.

\section{Hasil Analisis Korelasi}

Pada analisis ini, hubungan (korelasi) yang positif, ditunjukkan oleh adanya kesamaan penilaian antara pihak yang berkaitan. Sementara hubungan negatif, ditunjukkan apabila pendapat kedua pihak ada pertentangan. Tingkat kekuatan hubungan itu dilihat dari nilai sig. Jika nilai sig $<0.05$ maka berarti tingkat kesamaan pendapatnya signifikan, namun jika nilai sig $\geq 0.05$ maka tingkat kesamaan pendapatnya tidak signifikan.

Berdasarkan analisis program SPSS 16 pada aspek analisis korelasi, didapatkan hasil sebagai berikut:

a. Pengukuran kompetensi pedagogik terhadap kemampuan guru dalam menguasai karakteristik peserta didik dari aspek fisik, moral, sosial, kultural, emosional, dan intelektual.

\begin{tabular}{|c|c|c|c|c|}
\hline & & $\begin{array}{c}\text { Menguasai } \\
\text { karakteristik } \\
\text { siswa R1 }\end{array}$ & $\begin{array}{c}\text { Menguasai } \\
\text { karakteristik } \\
\text { siswa R3 }\end{array}$ & $\begin{array}{c}\text { Menguasai } \\
\text { karakteristik } \\
\text { siswa R2 }\end{array}$ \\
\hline \multirow{3}{*}{$\begin{array}{l}\text { Menguasai karakteristik } \\
\text { siswa R1 }\end{array}$} & Pearson Correlation & 1 & .083 & .048 \\
\hline & Sig. (2-tailed) & & .534 & .719 \\
\hline & $\mathrm{N}$ & 59 & 59 & 59 \\
\hline \multirow{3}{*}{$\begin{array}{l}\text { Menguasai karakteristik } \\
\text { siswa R3 }\end{array}$} & Pearson Correlation & .083 & 1 & .194 \\
\hline & Sig. (2-tailed) & .534 & & .140 \\
\hline & $\mathrm{N}$ & 59 & 60 & 59 \\
\hline \multirow{3}{*}{$\begin{array}{l}\text { Menguasai karakteristik } \\
\text { siswa R2 }\end{array}$} & Pearson Correlation & .048 & .194 & 1 \\
\hline & Sig. (2-tailed) & .719 & .140 & \\
\hline & $\mathrm{N}$ & 59 & 59 & 59 \\
\hline
\end{tabular}

b. Pengukuran kompetensi pedagogik terhadap kemampuan guru dalam menguasai teori belajar dan prinsip-prinsip pembelajaran yang mendidik.

\begin{tabular}{|c|c|c|c|c|}
\hline & & $\begin{array}{c}\text { Menguasai teori } \\
\text { R1 }\end{array}$ & $\begin{array}{c}\text { Menguasai teori } \\
\text { R2 }\end{array}$ & $\begin{array}{c}\text { Menguasai teori } \\
\text { R3 }\end{array}$ \\
\hline \multirow[t]{2}{*}{ Menguasai teori R1 } & Pearson Correlation & 1 & $.440^{*+*}$ & $\begin{array}{r}.098 \\
\end{array}$ \\
\hline & Sig. (2-tailed) & & .000 & .458 \\
\hline
\end{tabular}


Mimbar Sekolah Dasar, Volume 1 Nomor 2 Oktober 2014, (hal. 128-141)

\begin{tabular}{|l|l|r|r|r|}
\hline & $\mathrm{N}$ & 59 & 59 & 59 \\
\hline \multirow{3}{*}{ Menguasai teori R2 } & Pearson Correlation & $.440^{* *}$ & 1 & .233 \\
\cline { 2 - 5 } & Sig. (2-tailed) & .000 & & .075 \\
\cline { 2 - 5 } & $\mathrm{N}$ & 59 & 59 & 59 \\
\hline \multirow{3}{*}{ Menguasai teori R3 } & Pearson Correlation & .098 & .233 & 1 \\
\cline { 2 - 5 } & Sig. (2-tailed) & .458 & .075 & 60 \\
\cline { 2 - 5 } & $\mathrm{N}$ & 59 & 59 & \\
\hline
\end{tabular}

c. Pengukuran kompetensi pedagogik terhadap kemampuan guru dalam mengembangkan kurikulum yang terkait dengan mata pelajaran/bidang pengembangan yang diampu.

\begin{tabular}{|l|l|r|r|r|}
\hline & & $\begin{array}{c}\text { Mengembangkan } \\
\text { Kurikulum R1 }\end{array}$ & $\begin{array}{c}\text { Mengembangkan } \\
\text { Kurikulum R2 }\end{array}$ & $\begin{array}{c}\text { Mengembangkan } \\
\text { Kurikulum R3 }\end{array}$ \\
\hline $\begin{array}{l}\text { Mengembangkan } \\
\text { Kurikulum R1 }\end{array}$ & $\begin{array}{l}\text { Pearson } \\
\text { Correlation }\end{array}$ & 1 & -.080 & -.059 \\
\cline { 2 - 6 } & Sig. (2-tailed) & & .548 & .659 \\
\cline { 2 - 6 } & $\mathrm{N}$ & 59 & 59 & 59 \\
\hline $\begin{array}{l}\text { Mengembangkan } \\
\text { Kurikulum R2 }\end{array}$ & $\begin{array}{l}\text { Pearson } \\
\text { Correlation }\end{array}$ & -.080 & 1 & $.318^{*}$ \\
\cline { 2 - 6 } & Sig. (2-tailed) & .548 & 59 & .014 \\
\cline { 2 - 6 } & $\mathrm{N}$ & -.059 & $.318^{*}$ & 59 \\
\hline $\begin{array}{l}\text { Mengembangkan } \\
\text { Kurikulum R3 }\end{array}$ & $\begin{array}{l}\text { Pearson } \\
\text { Correlation }\end{array}$ & .659 & .014 & 60 \\
\cline { 2 - 6 } & Sig. (2-tailed) & 59 & 59 & \\
\cline { 2 - 6 } & $\mathrm{N}$ & & & 6 \\
\hline
\end{tabular}

d. Pengukuran kompetensi pedagogik terhadap kemampuan guru dalam menyelenggarakan pembelajaran yang mendidik.

\begin{tabular}{|l|l|r|r|r|}
\hline \multirow{4}{*}{ Pembelajaran mendidik R1 } & Pearson Correlation & $\begin{array}{c}\text { Pembelajaran } \\
\text { mendidik R1 }\end{array}$ & $\begin{array}{c}\text { Pembelajaran } \\
\text { mendidik R2 }\end{array}$ & $\begin{array}{c}\text { Pembelajaran } \\
\text { mendidik R3 }\end{array}$ \\
\cline { 2 - 5 } & Sig. (2-tailed) & 1 & $.388^{* *}$ & $.272^{*}$ \\
\cline { 2 - 5 } & $\mathrm{N}$ & 59 & .002 & .037 \\
\hline Pembelajaran mendidik R2 & Pearson Correlation & $.388^{* * *}$ & 59 & 59 \\
\cline { 2 - 6 } & Sig. (2-tailed) & .002 & 1 & $.375^{* *}$ \\
\cline { 2 - 6 } & $\mathrm{N}$ & 59 & 59 & .003 \\
\hline Pembelajaran mendidik R3 & Pearson Correlation & $.272^{*}$ & $.375^{* *}$ & 59 \\
\cline { 2 - 6 } & Sig. (2-tailed) & .037 & .003 & 1 \\
\cline { 2 - 6 } & $\mathrm{N}$ & 59 & 59 & 60 \\
\hline
\end{tabular}

e. Pengukuran kompetensi pedagogik terhadap kemampuan guru dalam memanfaatkan teknologi informasi dan komunikasi untuk kepentingan pembelajaran. 


\begin{tabular}{|l|l|r|r|r|}
\hline \multirow{3}{*}{ Manfaatkan Teknologi R1 } & $\begin{array}{c}\text { Manfaatkan } \\
\text { Teknologi R1 }\end{array}$ & $\begin{array}{c}\text { Manfaatkan } \\
\text { Teknologi R2 }\end{array}$ & $\begin{array}{c}\text { Manfaatkan } \\
\text { Teknologi R3 }\end{array}$ \\
\cline { 2 - 5 } & Pearson Correlation & 1 & $.383^{* *}$ & .213 \\
\cline { 2 - 5 } & Sig. (2-tailed) & & .003 & .106 \\
\cline { 2 - 5 } & $\mathrm{N}$ & 59 & 59 & 59 \\
\hline Manfaatkan Teknologi R2 & Pearson Correlation & $.383^{* *}$ & 1 & $.504^{* *}$ \\
\cline { 2 - 5 } & Sig. (2-tailed) & .003 & .000 \\
\cline { 2 - 6 } & $\mathrm{N}$ & 59 & 59 & 59 \\
\hline Manfaatkan Teknologi R3 & Pearson Correlation & .213 & $.504^{* *}$ & 1 \\
\cline { 2 - 6 } & Sig. (2-tailed) & .106 & .000 & 60 \\
\cline { 2 - 6 } & $\mathrm{N}$ & 59 & 59 & \\
\hline
\end{tabular}

f. Pengukuran kompetensi pedagogik terhadap kemampuan guru dalam memfasilitasi pengembangan potensi peserta didik untuk mengaktualisasikan berbagai potensi yang dimiliki.

\begin{tabular}{|l|l|r|r|r|}
\hline \multirow{2}{*}{} & & $\begin{array}{c}\text { Memfasilitasi } \\
\text { potensi siswa } \\
\text { R1 }\end{array}$ & $\begin{array}{c}\text { Memfasilitasi } \\
\text { potensi siswa } \\
\text { R2 }\end{array}$ & $\begin{array}{c}\text { Memfasilitasi } \\
\text { potensi siswa } \\
\text { R3 }\end{array}$ \\
\hline \multirow{3}{*}{$\begin{array}{l}\text { Memfasilitasi potensi siswa } \\
\text { R1 }\end{array}$} & Pearson Correlation & 1 & .206 & .016 \\
\cline { 2 - 5 } & Sig. (2-tailed) & & .117 & .903 \\
\cline { 2 - 6 } & $\mathrm{N}$ & 59 & 59 & 59 \\
\hline \multirow{3}{*}{$\begin{array}{l}\text { Memfasilitasi potensi siswa } \\
\text { R2 }\end{array}$} & Pearson Correlation & .206 & 1 & $.290^{*}$ \\
\cline { 2 - 6 } & Sig. (2-tailed) & .117 & 59 & .026 \\
\cline { 2 - 6 } & $\mathrm{N}$ & 59 & $.290^{*}$ & 59 \\
\hline \multirow{2}{*}{$\begin{array}{l}\text { Memfasilitasi potensi siswa } \\
\text { R3 }\end{array}$} & Pearson Correlation & .016 & .026 & 1 \\
\cline { 2 - 6 } & Sig. (2-tailed) & .903 & 59 & 60 \\
\cline { 2 - 6 } & $\mathrm{N}$ & 59 & & 59 \\
\hline
\end{tabular}

g. Pengukuran kompetensi pedagogik terhadap kemampuan guru dalam berkomunikasi secara efektif, empatik, dan santun dengan peserta didik.

\begin{tabular}{|c|c|c|c|c|}
\hline & & Komunikatif R1 & Komunikatif R2 & Komunikatif R3 \\
\hline \multirow[t]{3}{*}{ Komunikatif R1 } & Pearson Correlation & 1 & .191 & -.091 \\
\hline & Sig. (2-tailed) & & .148 & .492 \\
\hline & $\mathrm{N}$ & 59 & 59 & 59 \\
\hline \multirow[t]{3}{*}{ Komunikatif R2 } & Pearson Correlation & .191 & 1 & $.429^{* *}$ \\
\hline & Sig. (2-tailed) & .148 & & .001 \\
\hline & $\mathrm{N}$ & 59 & 59 & 59 \\
\hline \multirow[t]{3}{*}{ Komunikatif R3 } & Pearson Correlation & -.091 & $.429^{* * *}$ & 1 \\
\hline & Sig. (2-tailed) & .492 & .001 & \\
\hline & $\mathrm{N}$ & 59 & 59 & 60 \\
\hline
\end{tabular}


h. Pengukuran kompetensi pedagogik terhadap kemampuan guru dalam menyelenggarakan penilaian dan evaluasi proses dan hasil belajar.

\begin{tabular}{|l|l|r|r|r|}
\hline & & $\begin{array}{l}\text { Menyelenggarakan } \\
\text { evaluasi R1 }\end{array}$ & $\begin{array}{c}\text { Menyelenggarakan } \\
\text { evaluasi R2 }\end{array}$ & $\begin{array}{c}\text { Menyelenggarakan } \\
\text { evaluasi R3 }\end{array}$ \\
\hline \multirow{4}{*}{$\begin{array}{l}\text { Menyelenggarakan } \\
\text { evaluasi R1 }\end{array}$} & $\begin{array}{l}\text { Pearson } \\
\text { Correlation }\end{array}$ & 1 & .159 & -.025 \\
\cline { 2 - 6 } & Sig. (2-tailed) & 59 & .228 & .852 \\
\cline { 2 - 6 } & $\mathrm{N}$ & .159 & 59 & 59 \\
\hline \multirow{3}{*}{$\begin{array}{l}\text { Menyelenggarakan } \\
\text { evaluasi R2 }\end{array}$} & $\begin{array}{l}\text { Pearson } \\
\text { Correlation }\end{array}$ & .228 & 1 & $.484^{* *}$ \\
\cline { 2 - 6 } & Sig. (2-tailed) & 59 & 59 & .000 \\
\cline { 2 - 6 } & $\mathrm{N}$ & -.025 & $.484^{* *}$ & 59 \\
\hline \multirow{2}{*}{$\begin{array}{l}\text { Menyelenggarakan } \\
\text { evaluasi R3 }\end{array}$} & $\begin{array}{l}\text { Pearson } \\
\text { Correlation }\end{array}$ & .852 & .000 & 60 \\
\cline { 2 - 6 } & Sig. (2-tailed) & 59 & 59 & \\
\cline { 2 - 6 } & $\mathrm{N}$ & & & \\
\hline
\end{tabular}

i. Pengukuran kompetensi pedagogik terhadap kemampuan guru dalam memanfaatkan hasil penilaian dan evaluasi untuk kepentingan pembelajaran.

\begin{tabular}{|l|l|r|r|r|}
\hline \multirow{2}{*}{$\begin{array}{l}\text { Manfaatkan hasil evaluasi } \\
\text { R1 }\end{array}$} & $\begin{array}{c}\text { Manfaatkan } \\
\text { hasil evaluasi } \\
\text { R1 }\end{array}$ & $\begin{array}{c}\text { Manfaatkan } \\
\text { hasil evaluasi } \\
\text { R2 }\end{array}$ & $\begin{array}{c}\text { Manfaatkan } \\
\text { hasil evaluasi } \\
\text { R3 }\end{array}$ \\
\cline { 2 - 5 } & Pearson Correlation & 1 & .158 & .090 \\
\cline { 2 - 5 } & Sig. (2-tailed) & & .233 & .497 \\
\hline \multirow{2}{*}{$\begin{array}{l}\text { Manfaatkan hasil evaluasi } \\
\text { R2 }\end{array}$} & Pearson Correlation & 59 & 59 & 59 \\
\cline { 2 - 5 } & Sig. (2-tailed) & .158 & 1 & $.390^{* * *}$ \\
\cline { 2 - 6 } & $\mathrm{N}$ & 59 & 59 & .002 \\
\hline \multirow{2}{*}{$\begin{array}{l}\text { Manfaatkan hasil evaluasi } \\
\text { R3 }\end{array}$} & Pearson Correlation & .090 & $.390^{* * *}$ & 59 \\
\cline { 2 - 6 } & Sig. (2-tailed) & .497 & .002 & 6 \\
\cline { 2 - 6 } & $\mathrm{N}$ & 59 & 59 & 60 \\
\hline
\end{tabular}

j. Pengukuran kompetensi pedagogik terhadap kemampuan guru dalam melakukan tindakan reflektif untuk peningkatan kualitas pembelajaran.

\begin{tabular}{|l|l|r|r|r|}
\hline & & $\begin{array}{c}\text { Melakukan } \\
\text { refleksi R1 }\end{array}$ & $\begin{array}{c}\text { Melakukan } \\
\text { refleksi R2 }\end{array}$ & \multicolumn{1}{c|}{$\begin{array}{c}\text { Melakukan } \\
\text { refleksi R3 }\end{array}$} \\
\hline \multirow{3}{*}{ Melakukan refleksi R1 } & Pearson Correlation & 1 & .215 & -.215 \\
\cline { 2 - 6 } & Sig. (2-tailed) & & .101 & .101 \\
\cline { 2 - 6 } & $\mathrm{N}$ & 59 & 59 & 59 \\
\hline Melakukan refleksi R2 & Pearson Correlation & .215 & 1 & $-.330^{*}$ \\
\cline { 2 - 6 } & Sig. (2-tailed) & .101 & & .011 \\
\hline
\end{tabular}




\begin{tabular}{|l|l|r|r|r|}
\hline & $\mathrm{N}$ & 59 & 59 & 59 \\
\hline \multirow{3}{*}{ Melakukan refleksi R3 } & Pearson Correlation & -.215 & $-.330^{*}$ & 1 \\
\cline { 2 - 5 } & Sig. (2-tailed) & .101 & .011 & 60 \\
\cline { 2 - 6 } & $\mathrm{N}$ & 59 & 59 & \\
\hline
\end{tabular}

Berdasarkan penilaian terhadap semua aspek di atas, maka dapat disimpulkan bahwa tingkat hubungan di antara R1, R2 dan R3 secara keseluruhan dapat dilihat sebagai berikut:

\begin{tabular}{|l|l|r|r|r|}
\hline \multicolumn{5}{|c|}{ Correlations } \\
\hline \multirow{4}{*}{ Total R1 } & Total R1 & Total R2 & Total R3 \\
\cline { 2 - 5 } & Pearson Correlation & 1 & $.295^{*}$ & .137 \\
\cline { 2 - 5 } & Sig. (2-tailed) & & .023 & .302 \\
\cline { 2 - 5 } & $\mathrm{N}$ & 59 & 59 & 59 \\
\hline \multirow{3}{*}{ Total R2 } & Pearson Correlation & $.295^{*}$ & 1 & $.633^{*}$ \\
\cline { 2 - 5 } & Sig. (2-tailed) & .023 & & .000 \\
\cline { 2 - 5 } & $\mathrm{N}$ & 59 & 59 & 59 \\
\hline \multirow{3}{*}{ Total R3 } & Pearson Correlation & .137 & $.633^{* *}$ & 1 \\
\cline { 2 - 5 } & Sig. (2-tailed) & .302 & .000 & \\
\cline { 2 - 5 } & $\mathrm{N}$ & 59 & 59 & 60 \\
\hline
\end{tabular}

Melalui tabel di atas, dapat dijelaskan bahwa korelasi antara R1 dan R2 penilaiannya signifikan atau positif dengan perolehan sig.023, antara R1 dan R3 penilaiannya tidak signifikan atau negatif dengan perolehan sig.302, sementara korelasi antara R2 dan R3 penilaiannya signifikan atau positif dengan perolehan sig.000. Dengan demikian, secara umum dapat disimpulkan bahwa penilaian diri yang dilakukan oleh guru bersertifikat pendidik sesuai dengan penilaian yang diberikan oleh teman sejawat, namun tidak sesuai dengan penilaian yang diberikan oleh kepala sekolah.

\section{SIMPULAN}

Setelah dilakukan pengumpulan data, pengolahan dan analisis data, didapatkan kesimpulan sebagai berikut:

1. Kemampuan guru bersertifikat pendidik di kabupaten Sumedang dalam menguasai karakteristik peserta didik dari aspek fisik, moral, sosial, kultural, emosional, dan intelektual, berdasarkan jawaban dari semua responden berada pada kategori BAIK, dengan perolehan nilai 3,08 $(77,07 \%)$.

2. Kemampuan guru bersertifikat pendidik di kabupaten Sumedang dalam menguasai teori belajar dan prinsip-prinsip pembelajaran yang mendidik, berdasarkan jawaban dari semua responden berada pada kategori BAIK, dengan perolehan nilai 3,01 (75,28\%).

3. Kemampuan guru bersertifikat pendidik di kabupaten Sumedang dalam mengembangkan kurikulum yang terkait dengan mata pelajaran/bidang pengembangan yang diampu, berdasarkan jawaban dari semua responden berada pada kategori BAIK, dengan perolehan nilai 3,05 (76,17\%).

4. Kemampuan guru bersertifikat pendidik di kabupaten Sumedang dalam menyelenggarakan pembelajaran yang mendidik, berdasarkan jawaban dari semua responden berada pada kategori BAIK, dengan perolehan nilai 2,96 (74,04\%).

5. Kemampuan guru bersertifikat pendidik di kabupaten Sumedang dalam memanfaatkan teknologi informasi dan komunikasi untuk kepentingan pembelajaran, berdasarkan jawaban dari semua responden berada pada kategori BAIK, dengan perolehan nilai 2,96 (73,97\%).

6. Kemampuan guru bersertifikat pendidik di kabupaten Sumedang dalam memfasilitasi 
pengembangan potensi peserta didik untuk mengaktualisasikan berbagai potensi yang dimiliki, berdasarkan jawaban dari semua responden berada pada kategori BAIK, dengan perolehan nilai 2,96 (73,97\%).

7. Kemampuan guru bersertifikat pendidik di kabupaten Sumedang dalam berkomunikasi secara efektif, empatik, dan santun dengan peserta didik, berdasarkan jawaban dari semua responden berada pada kategori BAIK, dengan perolehan nilai 3,04 (75,91\%).

8. Kemampuan guru bersertifikat pendidik di kabupaten Sumedang dalam menyelenggarakan penilaian dan evaluasi proses dan hasil belajar, berdasarkan jawaban dari semua responden berada pada kategori BAIK, dengan perolehan nilai 3,06 (76,38\%).

9. Kemampuan guru bersertifikat pendidik di kabupaten Sumedang dalam memanfaatkan hasil penilaian dan evaluasi untuk kepentingan pembelajaran, berdasarkan jawaban dari semua responden berada pada kategori BAIK, dengan perolehan nilai 3,03 (75,80\%).

10. Kemampuan guru bersertifikat pendidik di kabupaten Sumedang dalam melakukan tindakan reflektif untuk peningkatan kualitas pembelajaran, berdasarkan jawaban dari semua responden berada pada kategori BAIK, dengan perolehan nilai 2,99 (74,76\%).

Berdasarkan sepuluh aspek di atas, rata-rata kompetensi pedagogis guru berada pada kategori BAIK, dengan perolehan nilai 3,02 $(75,48 \%)$. Namun apabila dilihat berdasarkan hasil korelasi jawaban, dimana jawaban antara R1 dan R2 banyak yang signifikan/sependapat, namun jawaban R3 banyak yang tidak signifikan/bertentangan, maka dapat diperoleh kesimpulan bahwa rata-rata kemampuan pedagogis guru bersertifikat pendidik di kabupaten Sumedang, berada pada kategori CUKUP berdasarkan jawaban dari 150 responden $(84,3 \%)$, dan berada pada kategori BAIK berdasarkan jawaban dari 28 responden $(15,7 \%)$.

\section{REFERENSI}

Bungin, Burhan. (2006). Metodologi Penelitian Kuantitatif. Edisi pertama. Jakarta:Kencana.

Danim, Sudarwan. (2002). Inovasi Pendidikan dalam Upaya Peningkatan Profesionalisme Tenaga Kependidikan. Bandung: Pustaka Setia.

Fahdini, Reni. dkk. (2013). Identifikasi Kompetensi Guru Sebagai Cerminan Profesionalisme Tenaga Pendidik di Kabupaten Sumedang. Laporan Penelitian Jarlit Bapeda Kab. Sumedang.

Nazir, Mohammad. (2005). Metode Penelitian. Bogor : Ghalia Indonesia.

Undang-Undang Republik Indonesia Nomor 14 Tahun 2005 Tentang Guru dan Dosen.

Widoyoko, S. Eko Putro. (2008). Peranan Sertifikasi Guru dalam Meningkatkan Mutu Pendidikan. [Online]. Tersedia: http://www.umpwr.ac.id/download/publikasi

ilmiah/Peranan\%20Sertifikasi\%20Guru\%20dal am\%20Meningkatkan\%20Mutu\%20Pendidika n.pdf. [29 Maret 2013].

Yasin, Ahmad Fatah. (2011). "Pengembangan Kompetensi Pedagogik Guru Pendidikan Agama Islam di Madrasah (Studi Kasus di MIN Malang I)". Jurnal el-QUDWAH, Vol. 1 No. 5 April 2011. [Online]. Tersedia: http://ejournal.uin-

malang.ac.id/index.php/lemlit/article/downlo ad/1942/pdf. [06 Maret 2014].

Yulianti, Fitri. (2012). "Hubungan Kompetensi Pedagogik Guru PAI dengan Prestasi Belajar pada Mata Pelajaran PAI (Studi Deskriptif pada Guru PAI di SMP Negeri Kota Indramayu)". Jurnal Tarbawi, Vol. 1 No. 2 Juni 2012. [Online]. Tersedia: http://jurnal.upi.edu/file/04_Hubungan_Kom petensi_Pedagogik_Guru_PAI__Fitri_Yulianti.pdf. [06 Maret 2014]. 